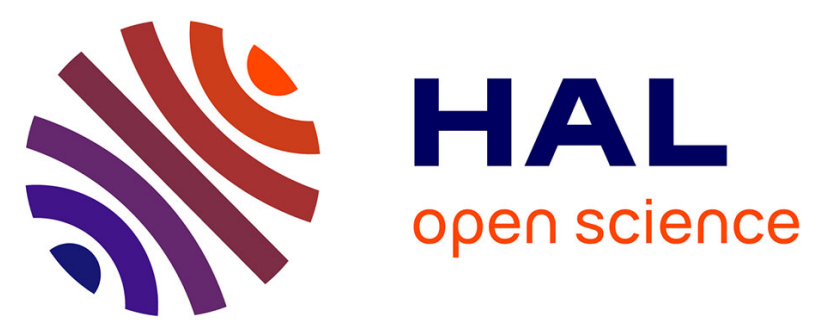

\title{
Applications of Lanthanide Trichloride Hydrates, Prepared from Mischmetall, in the Biginelli Reaction
}

Marie-Isabelle Lannou, Florence Hélion, Jean-Louis Namy

\section{To cite this version:}

Marie-Isabelle Lannou, Florence Hélion, Jean-Louis Namy. Applications of Lanthanide Trichloride Hydrates, Prepared from Mischmetall, in the Biginelli Reaction. SYNLETT, 2008, 2008 (1), pp.105107. 10.1055/s-2007-992387 . hal-02371229

\section{HAL Id: hal-02371229 \\ https://hal.science/hal-02371229}

Submitted on 5 Oct 2021

HAL is a multi-disciplinary open access archive for the deposit and dissemination of scientific research documents, whether they are published or not. The documents may come from teaching and research institutions in France or abroad, or from public or private research centers.
L'archive ouverte pluridisciplinaire HAL, est destinée au dépôt et à la diffusion de documents scientifiques de niveau recherche, publiés ou non, émanant des établissements d'enseignement et de recherche français ou étrangers, des laboratoires publics ou privés. 


\title{
Applications of Lanthanide Trichloride Hydrates, Prepared from Mischmetall, in the Biginelli Reaction
}

\author{
Marie-Isabelle Lannou, Florence Hélion, Jean-Louis Namy* \\ Laboratoire de Catalyse Moléculaire CNRS, ICMMO, Bât 420, Université Paris-Sud, 91405 Orsay, France \\ Fax +33(1)69154680; E-mail: flohelion@icmo.u-psud.fr
}

\begin{abstract}
An inexpensive alloy of light lanthanides, called mischmetall, has been used in the preparation of a mixture of lanthanide trichloride hydrates. The use of this new type of material is described in Biginelli reactions.
\end{abstract}

Key words: mischmetall, lanthanide trichlorides, Biginelli-type reaction

We have reported, in a preceding letter, ${ }^{1}$ a simple method for the preparation of a mixture of lanthanide trichloride hydrates directly from mischmetall and hydrochloric acid (Scheme 1). We used this new reagent in stoichiometric amounts in the Luche-type reduction to prepare allylic alcohols or allyl alkyl ethers. Results showed that mischmetall trichloride hydrates were as efficient as cerium trichloride hydrates.

$$
\begin{aligned}
& \mathrm{Ln}+3 \mathrm{HCl} \\
& \mathrm{Ln}=\text { mischmetall (ingots) }
\end{aligned}
$$

Scheme 1 Synthesis of lanthanide trichloride hydrates from mischmetall ingots

Herein we wish to report the first use of this new material as a catalyst. We studied the synthesis of 3,4-dihydropyrimidin-2-(1H)-ones obtained by a one-pot Biginelli-type reaction and compared the reactivity of this catalyst with classically-used trichloride hydrates derived from pure lanthanide metals.

In 1893, Biginelli reported the first synthesis of 3,4-dihydropyrimidin-2-(1H)-ones (DHPMs) via a one-pot reaction involving aromatic aldehydes, urea (or thiourea) and ethyl acetoacetate in an ethanolic solution under acidic conditions (Scheme 2). ${ }^{2}$

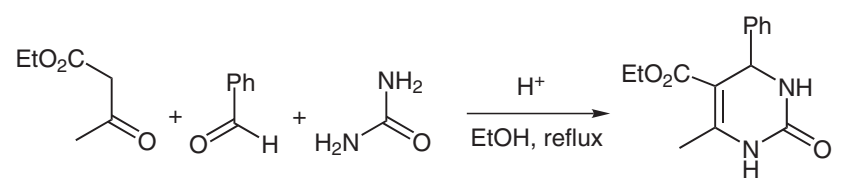

Scheme 2 Typical Biginelli-type reaction
These multicomponent reactions (MCRs), unexplored until the 1980s, have attracted considerable attention over the past decade, since dihydropyrimidin-2(1H)-ones and their derivatives were found to display a fascinating array of pharmacological and therapeutic properties. ${ }^{3}$ DHPMs have been developed as antiviral, antibacterial or antihypertensive agents, $\alpha_{1 \mathrm{a}}$-antagonists, neuropeptide Y (NPY) antagonists or potent calcium channel blockers. Moreover, recently marine alkaloids have been isolated that contain a dihydropyrimidinone-5-carboxylate core (the batzelladine alkaloids), and these alkaloids were found to be potent HIV gp-120-CD4 inhibitors. ${ }^{4}$

The initial one-pot Biginelli procedure, catalyzed by hydrochloric acid in ethanolic solution, suffers from major drawbacks such as long reaction times and low yields, especially when aliphatic and substituted aromatic aldehydes are used. Recently, growing interest in MCRs and the elucidation of the mechanism of the Biginelli reaction have been combined to considerably improve the efficiency of the reaction. Various strategies have been developed to overcome problems: among these are multistep synthetic strategies, ${ }^{5}$ improvement of the one-pot procedure using acidic clay, ${ }^{6}$ ionic liquids, ${ }^{7}$ microwave irradiation under solventless conditions ${ }^{8}$ or catalysis using Lewis acids $\left(\mathrm{BiCl}_{3}, \mathrm{BF}_{3} \cdot \mathrm{OEt}_{2}-\mathrm{CuCl} / \mathrm{H}^{+}, \mathrm{InCl}_{3}\right) .{ }^{9}$ Lanthanide complexes have also proved to be efficient catalysts in the Biginelli-type reaction: asymmetric synthesis of dihydropyrimidin-2(1H)-ones has been demonstrated using $\mathrm{CeCl}_{3}$ or $\mathrm{Ln}(\mathrm{OTf})_{3}(\mathrm{Ln}=\mathrm{La}, \mathrm{Sm} \text { or } \mathrm{Yb})^{10}$ with chiral ligands and original processes such as parallel synthesis using solidsupported ytterbium(III). ${ }^{11}$ Cerium(IV) ammonium nitrate has also been used as a catalyst. ${ }^{12}$ In this field, lanthanide complexes are very interesting since these mild Lewis acids are environmentally friendly $\left(\mathrm{LaCl}_{3} \cdot 7 \mathrm{H}_{2} \mathrm{O}\right)^{13}$ and some of them can easily be recycled $\left[\mathrm{Ln}(\mathrm{OTf})_{3}\right]^{14}$ Nevertheless, many of these methods involve expensive reagents; therefore, we wish to report the direct synthesis of 3,4-dihydropyrimidin-2(1H)-ones using lanthanide trichloride heptahydrates derived from mischmetall. This inexpensive catalyst can be easily prepared in a one-step procedure from mischmetall and promotes the Biginelli reaction under mild conditions (Scheme 3 ).

Evaluation of the efficacy of $\mathrm{LnCl}_{3} \cdot 7 \mathrm{H}_{2} \mathrm{O}$ in a Biginellitype reaction is relevant due to a communication by $\mathrm{Lu}$ et al. ${ }^{13}$ describing a similar study using lanthanum chloride (50 mol\%/aldehyde) as a catalyst. 


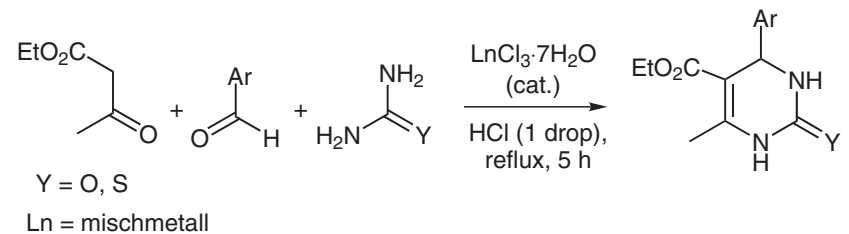

Scheme 3 Biginelli reaction catalyzed by lanthanide trichloride hydrates

Our results are presented in Table 1. A test reaction was carried out with benzaldehyde, urea and ethyl acetoacetate; the use of 0.2 equivalent (entry 2) instead of 0.5 equivalent of $\mathrm{LnCl}_{3} \cdot 7 \mathrm{H}_{2} \mathrm{O}$ (entry 1 ) did not significantly affect the yield. In both cases, reaction time could be reduced to five hours instead of 18 hours under classical Biginelli conditions. Furthermore, urea could be easily replaced by thiourea (entry 3 ) without significantly decreasing the yields (entries 2 vs. 3 and 4 vs. 6). Therefore, we chose to lower the catalyst amount to $20 \mathrm{~mol} \%$ from 50 mol\%. ${ }^{13}$ Two general cases were observed:

1) Benzaldehyde or activated aromatic aldehydes produced DHPMs in good yields (entries 1-6, 9 and 10), even with low catalyst loading and in the absence of hydrochloric acid. However, when the reaction was performed with $p$-hydroxybenzaldehyde, it was necessary to increase the amount of catalyst to obtain the DHPM in good yield (entries 11 and 12); this may be due to catalyst coordination to the free hydroxyl group. When hydrochloric acid was not added to the reaction, lower yields were always observed (entries 5, 8 and 10).

2) When deactivated aromatic aldehydes were used (entries 7, 8, 13 and 14) yields were lower, but remained satisfactory. However, in these cases, the lack of hydrochloric acid seemed to have a dramatic influence on the completion of the reaction (entries 7 and 8).

A comparison of our results with those published by Lu et al. ${ }^{13}$ showed that using a mixture of lanthanide trichlorides instead of lanthanum trichloride heptahydrate did not significantly affect the yields of DHPMs or reaction times. We demonstrated that the amount of catalyst could be lowered to 0.2 equivalent without significantly decreasing the yield. In all cases, the reaction was about three times faster than the original Biginelli reaction and the yields were improved (classical conditions: catalytic $\mathrm{HCl}$ in $\mathrm{EtOH}$, reflux, $18 \mathrm{~h})$. $^{2,13}$

The mechanism of the Biginelli reaction has recently been revised by Kappe. ${ }^{16}$ Based on this work we suggest the following mechanism for the $\mathrm{LnCl}_{3} \cdot 7 \mathrm{H}_{2} \mathrm{O}$-catalyzed Biginelli reaction (Scheme 4).

The first step is the acid-catalyzed condensation of aldehyde and urea (or thiourea). The formation of $\mathrm{N}$-acyl imine intermediate $\mathbf{A}$ is the rate-limiting step of the reaction. The intermediate $\mathbf{A}$ is complexed by lanthanide chlorides, giving B, which acts as an electrophile for the nucleophilic addition of the ketoester enol. The resulting adduct $\mathrm{C}$ undergoes condensation with the urea- $\mathrm{NH}_{2}$ to give the cyclized product $\mathbf{D}$.
Table 1 Use of $\mathrm{LnCl}_{3} \cdot 7 \mathrm{H}_{2} \mathrm{O}$ as Catalyst in Biginelli-Type Reaction ${ }^{15}$

\begin{tabular}{|c|c|c|c|c|c|}
\hline Entry & $\mathrm{Ar}$ & $\mathrm{Y}$ & $\begin{array}{l}\text { Catalyst } \\
\text { (equiv) }\end{array}$ & Product & $\begin{array}{l}\text { Yield } \\
(\%)^{\mathrm{a}}\end{array}$ \\
\hline 1 & $\mathrm{Ph}$ & $\mathrm{O}$ & 0.5 & 1 & 92 \\
\hline 2 & $\mathrm{Ph}$ & $\mathrm{O}$ & 0.2 & 1 & 85 \\
\hline 3 & $\mathrm{Ph}$ & $S$ & 0.2 & 2 & 83 \\
\hline 4 & 4- $\mathrm{MeOC}_{6} \mathrm{H}_{4}$ & $\mathrm{O}$ & 0.2 & 3 & 84 \\
\hline 5 & 4- $\mathrm{MeOC}_{6} \mathrm{H}_{4}$ & $\mathrm{O}$ & 0.2 & 3 & $64^{\mathrm{b}}$ \\
\hline 6 & $4-\mathrm{MeOC}_{6} \mathrm{H}_{4}$ & $\mathrm{~S}$ & 0.2 & 4 & 88 \\
\hline 7 & $3-\mathrm{BrC}_{6} \mathrm{H}_{4}$ & $\mathrm{O}$ & 0.2 & 5 & 82 \\
\hline 8 & $3-\mathrm{BrC}_{6} \mathrm{H}_{4}$ & $\mathrm{O}$ & 0.2 & 5 & $36^{\mathrm{b}}$ \\
\hline 9 & $4-\mathrm{ClC}_{6} \mathrm{H}_{4}$ & $\mathrm{O}$ & 0.2 & 6 & 83 \\
\hline 10 & $4-\mathrm{ClC}_{6} \mathrm{H}_{4}$ & $\mathrm{O}$ & 0.2 & 6 & $68^{\mathrm{b}}$ \\
\hline 11 & $4-\mathrm{HOC}_{6} \mathrm{H}_{4}$ & $\mathrm{O}$ & 0.2 & 7 & 56 \\
\hline 12 & $4-\mathrm{HOC}_{6} \mathrm{H}_{4}$ & $\mathrm{O}$ & 0.5 & 7 & 80 \\
\hline 13 & $4-\mathrm{O}_{2} \mathrm{NC}_{6} \mathrm{H}_{4}$ & $\mathrm{O}$ & 0.2 & 8 & 31 \\
\hline 14 & $4-\mathrm{O}_{2} \mathrm{NC}_{6} \mathrm{H}_{4}$ & $\mathrm{O}$ & 0.5 & 8 & 75 \\
\hline 15 & furyl & $\mathrm{O}$ & 0.5 & 9 & 56 \\
\hline
\end{tabular}

${ }^{\text {a }}$ Yields of pure products (after recrystallization).

${ }^{\mathrm{b}}$ The reaction was performed without $\mathrm{HCl}$.

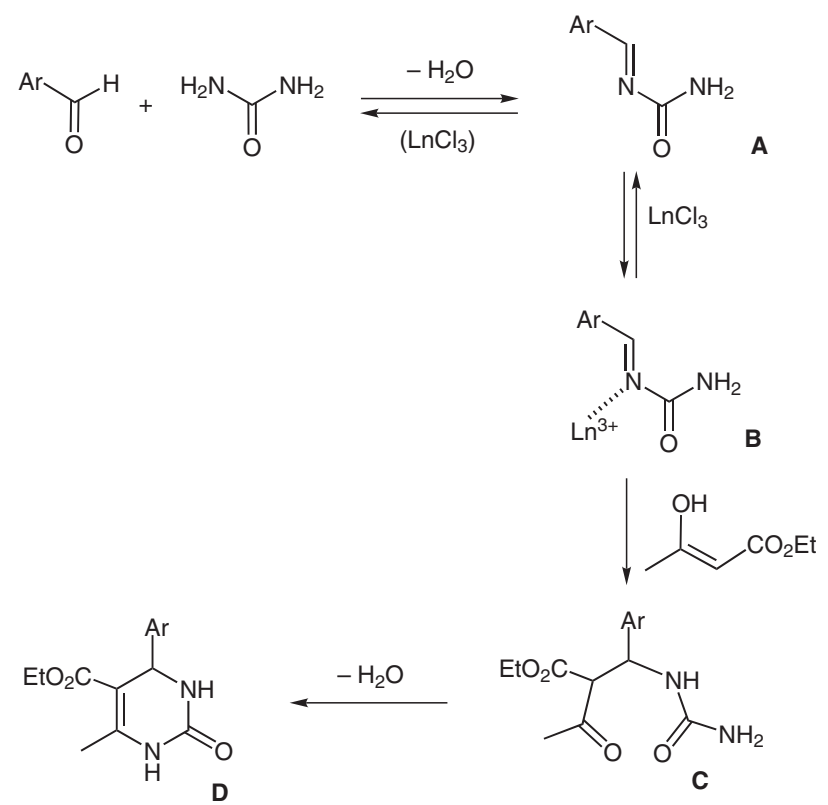

Scheme 4 Assumed mechanism for $\mathrm{LnCl}_{3} \cdot 7 \mathrm{H}_{2} \mathrm{O}$-catalyzed Biginelli reaction

Lanthanide trichloride hydrates prepared from mischmetall can be used as catalysts for the Biginelli-type cyclocondensation. This method not only preserves the simplicity of the initial one-pot reaction, but also noticeably improves the yields of DHPM and reduces reaction times. 
This example is the first example of the use of mischmetall trichloride hydrates as catalyst in organic synthesis. This material could be tested in a wide variety of reactions involving lanthanide salts as catalyst.

\section{Acknowledgment}

We thank University of Paris-Sud and CNRS for their financial support.

\section{References and Notes}

(1) Lannou, M.-I.; Hélion, F.; Namy, J.-L. Synlett 2007, 2707.

(2) Biginelli, P. Gazz. Chim. Ital. 1893, 23, 360.

(3) For a review, see: (a) Kappe, C. O. Tetrahedron 1993, 49, 6937; and references cited therein. (b) Kappe, C. O. Acc. Chem. Res. 2000, 33, 879.

(4) Patil, A. D.; Kumar, N. V.; Kokke, W. C.; Bean, M. F.; Freyer, A. J.; De Brosse, C.; Mai, S.; Truneh, A.; Faulkner, D. J.; Carte, B.; Breen, A. L.; Hertzberg, R. P.; Johnson, R. K.; Wesley, J. W.; Potts, B. C. M. J. Org. Chem. 1995, 60, 1182.

(5) (a) Atwal, K. S.; O’Reilly, B. C. Heterocycles 1987, 26, 1185. (b) Atwal, K. S.; O'Reilly, B. C.; Gougoutas, J. Z.; Malley, M. F. Heterocycles 1987, 26, 1189.

(6) Bigi, F.; Carloni, S.; Frullanti, B.; Maggi, R.; Sartori, G. Tetrahedron Lett. 1999, 40, 3465.

(7) Peng, J.; Deng, Y. Tetrahedron Lett. 2001, 42, 5917.

(8) Kappe, C. O.; Kuman, D.; Varma, R. S. Synthesis 1999, 1799.

(9) (a) Ramalinga, K.; Vijayalakshmi, P.; Kaimal, T. N. B. Synlett 2001, 863. (b) Hu, E. H.; Sidler, D. R.; Dolling, U.H. J. Org. Chem. 1998, 63, 3454. (c) Munoz-Muniz, O.; Juaristi, E. ARKIVOC 2003, (xi), 16.

(10) Huang, Y.; Fengyue, Y.; Zhu, C. J. Am. Chem. Soc. 2005, 127, 16386.

(11) Dondoni, A.; Massi, A. Tetrahedron Lett. 2001, 42, 7975

(12) Yadav, J. S.; Reddy, B. V. S.; Reddy, K. B.; Raj, K. S.; Prasad, A. R. J. Chem. Soc., Perkin Trans. 1 2001, 1939.

(13) Lu, J.; Bai, Y.; Wang, Z.; Yang, B.; Ma, H. Tetrahedron Lett. 2000, 41, 9075; and references cited therein.

(14) Ma, Y.; Qian, C.; Wang, L.; Yang, M. J. Org. Chem. 2000, $65,3864$.
(15) Typical Experimental Procedure for Biginelli Reaction: A mixture of ethyl acetoacetate $(638 \mu \mathrm{L}, 5 \mathrm{mmol})$, urea (451 $\mathrm{mg}, 7.5 \mathrm{mmol})$ or thiourea $(571 \mathrm{mg}, 7.5 \mathrm{mmol})$, aldehyde (5 $\mathrm{mmol}), \mathrm{LnCl}_{3} \cdot 7 \mathrm{H}_{2} \mathrm{O}(\mathrm{Ln}=$ mischmetall, $373 \mathrm{mg}, 1 \mathrm{mmol}$, 0.2 equiv) and $12 \mathrm{M} \mathrm{HCl}$ acid (1 drop) in absolute $\mathrm{EtOH}$ (10 $\mathrm{mL}$ ) was placed under magnetic stirring and refluxed in EtOH for $5 \mathrm{~h}$. The reaction mixture was then cooled to r.t. and poured onto an ice-water mixture $(25 \mathrm{~g})$. The solution was stirred for $5 \mathrm{~min}$ until a solid appeared. The precipitate was then filtered and the solid was washed with cold $\mathrm{H}_{2} \mathrm{O}$ $(2 \times)$, then with an $\mathrm{EtOH}-\mathrm{H}_{2} \mathrm{O}$ mixture $(1: 1,2 \times)$ and finally dried under vacuum. The crude product was then purified by recrystallization in absolute EtOH.

Selected Spectral Data for 6-Methyl-2-oxo-4-phenyl1,2,3,4-tetrahydropyrimidine-5-carboxylic Acid Ethyl Ester (1): colorless crystals; mp 207-209 ${ }^{\circ} \mathrm{C}$ (lit. ${ }^{8} \mathrm{mp} 206-$ $209^{\circ} \mathrm{C}$ ); yield: $1.954 \mathrm{~g}, 92 \%$ (cat.: 0.5 equiv); yield: $1.106 \mathrm{~g}$, $85 \%$ (cat.: 0.2 equiv). ${ }^{1} \mathrm{H} \mathrm{NMR}\left(250 \mathrm{MHz}, \mathrm{CDCl}_{3}\right): \delta=1.16$ (t, $J_{\mathrm{CH} 3-\mathrm{CH} 2}=7.1 \mathrm{~Hz}, 3 \mathrm{H}, \mathrm{OEt}$ ), $2.35[\mathrm{~s}, 3 \mathrm{H}, \mathrm{C}(6) \mathrm{Me}$ ], 4.07 $\left(\mathrm{q}, J_{\mathrm{CH} 2-\mathrm{CH} 3}=7.1 \mathrm{~Hz}, 2 \mathrm{H}, \mathrm{OEt}\right), 5.40\left[\mathrm{~d}, J_{4,3}=2.9 \mathrm{~Hz}, 1 \mathrm{H}\right.$, $\mathrm{C}(4) \mathrm{H}], 5.65$ [br s, $1 \mathrm{H}, \mathrm{N}(3) \mathrm{H}], 7.31\left(\mathrm{~m}, 5 \mathrm{H}, \mathrm{H}_{\mathrm{ar}}\right), 7.97$ [br s, $1 \mathrm{H}, \mathrm{N}(1) \mathrm{H}] .{ }^{13} \mathrm{C}$ NMR $(62.9 \mathrm{MHz}, \mathrm{DMSO}): \delta=15.0$, 18.7, 54.9, 60.2, 100.2, 127.2, 128.2, 129.3, 145.8, 149.3, 153.1, 166.3. FTIR (NaCl, nujol): $3233,3110,1728,1704$, 1644, 1378, 1309, 1290, 1232, 1220, 1090, 779, 758, 681 $\mathrm{cm}^{-1}$. GC-MS(electrospray): $\mathrm{m} / \mathrm{z}(\%)=543.3(89)[2 \times \mathrm{M}+$ $\mathrm{Na}]^{+}, 315.2$ (60), $283.1(100)[\mathrm{M}+\mathrm{Na}]^{+}$. 4-(4-Methoxyphenyl)-6-methyl-2-thioxo-1,2,3,4-tetrahydro-pyrimidine-5-carboxylic Acid Ethyl Ester (4): colorless crystals; mp $149-151^{\circ} \mathrm{C}$ (lit. $.^{17} \mathrm{mp} 150-152{ }^{\circ} \mathrm{C}$ ); yield: $1.347 \mathrm{~g}, 88 \%$. ${ }^{1} \mathrm{H}$ NMR $\left(250 \mathrm{MHz}, \mathrm{CDCl}_{3}\right): \delta=1.10\left(\mathrm{t}, J_{\mathrm{CH} 3-\mathrm{CH} 2}=7.1 \mathrm{~Hz}\right.$, $3 \mathrm{H}, \mathrm{OEt}$ ), 2.26 [s, $3 \mathrm{H}, \mathrm{C}(6) \mathrm{Me}$ ], 3.71 (s, $3 \mathrm{H}, \mathrm{OMe}$ ), 4.00 $\left(\mathrm{q}, J_{\mathrm{CH} 2-\mathrm{CH} 3}=7.1 \mathrm{~Hz}, 2 \mathrm{H}, \mathrm{OEt}\right), 5.28\left[\mathrm{~d}, J_{4,3}=2.9 \mathrm{~Hz}, 1 \mathrm{H}\right.$, $\mathrm{C}(4) \mathrm{H})], 5.80[\mathrm{br} \mathrm{s}, 1 \mathrm{H}, \mathrm{N}(3) \mathrm{H}], 6.76\left[\mathrm{~d}, J_{3^{\prime}, 2^{\prime}}=J_{5^{\prime}, 6^{\prime}}=8.6\right.$ $\left.\left.\mathrm{Hz}, 2 \mathrm{H}, \mathrm{C}\left(3^{\prime}\right) \mathrm{H}, \mathrm{C}\left(5^{\prime}\right) \mathrm{H}\right)\right], 7.16\left[\mathrm{~d}, J_{2^{\prime}, 3^{\prime}}=J_{6^{\prime}, 5^{\prime}}=8.6 \mathrm{~Hz}, 2 \mathrm{H}\right.$, $\left.\mathrm{C}\left(2^{\prime}\right) \mathrm{H}, \mathrm{C}\left(6^{\prime}\right) \mathrm{H}\right], 8.26$ [br s, $\left.1 \mathrm{H}, \mathrm{N}(1) \mathrm{H}\right] .{ }^{13} \mathrm{C}$ NMR $(62.9$ MHz, DMSO): $\delta=15.0,18.0,54.4,56.0,60.5,101.9,114.8$, 128.5, 136.6, 145.7, 159.7, 166.1, 174.9. FTIR ( NaCl, nujol): $3305,3161,3097,1666,1574,1510,1331,1270$, $1120,1023 \mathrm{~cm}^{-1}$. GC-MS(electrospray): $\mathrm{m} / \mathrm{z}(\%)=636.2$ (25) $[(2 \times \mathrm{M}+1)+\mathrm{Na}]^{+}, 635.2(68)[2 \times \mathrm{M}+\mathrm{Na}]^{+}, 330.1$ (18), $329.1(100)[\mathrm{M}+\mathrm{Na}]^{+}, 307.1(35)$.

(16) Kappe, C. O. J. Org. Chem. 1997, 62, 7201.

(17) Fu, N.-Y.; Yuan, Y.-F.; Cao, Z.; Wang, S.-W.; Wang, J.-T.; Peppe, C. Tetrahedron 2002, 58, 4801. 